\title{
Co-Creating Innovative Tourist Experiences: Towards an Integrative Framework
}

Sharma, P. and Malik, G. and Leung, T.Y.

\begin{abstract}
Co-creating tourist experiences helps create value for the tourists resulting from their interactions with tourism service providers and the physical environment. However, the practices and procedures that drive the co-creation of innovative tourist experiences are still not clear. We address this research gap by combining the resource-based view (RBV) and service-dominant (S-D) logic to develop specific hypotheses about the mediating role of value co-creation in the process by which internal and external resource orientations impact radical and incremental innovations, which in turn influence tourist experience and outcomes (brand advocacy and revisit intentions). We find support for most of our hypotheses using partial least squares structural equation modeling (PLS-SEM) to analyze data from matching samples of 191 tourists and managers in tourism provider firms in India. Specifically, external (but not internal) resource orientation positively affects both incremental and radical innovations, which in turn positively impact tourist experience, brand advocacy and revisit intentions. Finally, value co-creation fully mediates the positive effect of internal (but not external) resource orientation on both incremental and radical innovations. These findings would help tourism providers design co-creative and innovative tourism strategies to manage and improve tourist experiences as well as their brand advocacy and revisit intentions.
\end{abstract}

Keywords: incremental innovation; radical innovation; resource orientation; tourist experience; value co-creation 


\section{Introduction}

Tourism was ranked among the fastest growing sectors in the service industry before Covid-19 pandemic brought this sector to a grinding halt since early 2020 (Daglis \& Katsikogianni, 2021). Now, as the whole world prepares to emerge from under the dark shadows of Covid-19 pandemic, service innovation is expected to play a vital role to help the tourism-based economies to recover from its devastating impact (Casais et al., 2020; Sharma et al., 2021). In fact, even before Covid-19 pandemic, the growing competition had forced destination marketing organizations (DMO) to explore innovative measures to create memorable experiences for tourists and to sustain the competitiveness of tourism destinations (Cavalheiro et al., 2020; Del Chiappa \& Baggio, 2015; Neuhofer, 2016; Oxenswardh, 2018; Prebensen et al., 2018). Therefore, it is not surprising to see tourism organizations rely on innovative measures to stay relevant in a competitive environment while presenting their destinations in different ways to attract more visitors (Rejón-Guardia et al., 2020; Troisi et al., 2019; Zuñiga-Collazos et al., 2020).

Being innovative also helps tourism service providers to improve their performance by addressing the tourists' increasingly sophisticated and diverse needs, and ensuring availability of numerous tourist destinations and safety of the tourists, besides saving the tourists' costs, time, and other resources (Artal-Tur, 2020; Satta et al., 2019). In this context, many tourism and hospitality firms have adopted co-creation of their services as an innovative practice, to provide their tourists with unique and engaging experiences (Tu et al., 2018; Rihova et al., 2018). Co-creating tourist experiences also helps make customers familiar with the service environment and set their expectations for the services to be provided (Bhat \& Sharma, 2021; Casais et al., 2020; Giaccone \& Bonacini, 2019). Thus, cocreation of tourist experiences is increasingly becoming critical for tourism providers to improve their performance (Font et al., 2021; Roy et al., 2020). 
There is growing evidence about the role of value co-creation in service innovation, such as social innovation (Polese et al., 2018) and online platforms (Casais et al., 2020). For example, Polese et al. (2018) use ten interviews with Bed and Breakfast (B\&B) owners to analyze their perception of the main dimensions of smart service ecosystems. Similarly, Casais et al. (2020) use a qualitative analysis of 30 in-depth interviews with hosts of peer-topeer accommodation (Airbnb) in Portugal, to highlight the importance of relationship marketing during the guests' stay. However, most of these studies are either descriptive or conceptual; hence, in the absence of robust empirical studies, the process by which tourism providers can use their internal and external resources to co-create tourist experiences, still remains unclear (Mohammadi et al., 2020; Phi \& Dredge, 2019).

In addition, despite the growing popularity of service innovations, there is still no consensus about their impact on the performance of tourism companies, with doubts being raised about the process of digital transformation (De Bernardi et al., 2019) and the possibility of negative effect of innovation on organizational competitiveness (ZuñigaCollazos et al., 2020). As a result, the impact of co-created tourist experiences on important customer outcomes, such as brand advocacy and revisit intentions is also unclear. Finally, most current research on this topic also consists of qualitative and conceptual studies, which further limits their practical application and generalizability (Font et al., 2021; Sørensen \& Jensen, 2019). We address all these research gaps in this paper.

First, we combine the resource-based view (RBV) of the firm (Barney, 2001; Set et al., 2017; Vo Thanh et al., 2020) and the service-dominant (S-D) logic (Mishra \& Gupta, 2019; Troisi et al., 2019; Vargo \& Lusch, 2004; 2008; 2017) to distinguish between the internal and external resource orientations of the tourism firms and hypothesize their influence on value co-creation. Next, we hypothesize the impact of value co-creation on the two types of service innovation, namely incremental and radical innovations (Martínez-Pérez et al., 2019; Satta et 
al., 2019; Souto, 2015), and the influence of these innovations on tourist experience. Finally, we hypothesize the effects of tourist experience on two important tourist outcomes, namely brand advocacy and revisit intentions (Zhong et al., 2017). Figure 1 shows our conceptual model with all these hypotheses.

We tested all our hypotheses in the context of a co-creative virtual platform as a service innovation to enhance the tourist experience using the data collected from a matching sample of 191 tourists and service providers in India just before the Covid-19 lockdowns (January March, 2020). We adapted well-established scales to operationalize all the constructs included in our conceptual model and found support for most of our hypotheses using partial least square structural equation modeling (PLS-SEM) technique with Smart PLS-3. We begin this paper with a review of the relevant literature on all the constructs included in our conceptual model and then develop specific hypotheses about their relationships with each

other. We then describe our empirical study, data collection and analysis. Finally, we discuss the theoretical and practical implications of our results and the limitations of this study along with some useful directions for future research in this area of growing importance.

\section{Literature Review and Theoretical Background}

\section{Resource-Based View (RBV)}

The resource-based view (RBV) argues that a firm becomes more competent than its rivals if it develops valuable, exceptional, non-imitable resources that cannot be substituted and which help the firm achieve competitive advantage through superior performance (Barney, 2001). This view has been applied in the tourism context to study topics, such as management practices used by tourism firms (Set et al., 2017) and the role of organizational ambidexterity (Vo Thanh et al., 2020). Past research identifies two extensions of resourcebased view: (i) the nature of the organization and (ii) the combination of an organization's 
resources and processes, to study the attributes of distinctive competitive advantages. While the early view of RBV focused on the diverse nature of the resources, recent studies explore the combination of these resources and their multiple uses (Varadarajan, 2020).

RBV framework has also been used for developing competitive resources in tourism (Evans, 2016; Line \& Runyan, 2014; Pyke et al., 2016). However, few studies explore the need for tourism firms to optimize their internal and external resources to improve their performance and offer mixed evidence (Set et al., 2017; Vo Thanh et al., 2020). For example, Satta et al. (2019) use a systematic literature review to show conflicting results about the impact of green and sustainable innovation in the tourism industry. Similarly, ZuñigaCollazos et al. (2020) find a negative effect of innovation on the competitiveness of tourism companies in Colombia, whereas Lentu et al. (2021) find a positive impact of resource orientation on the performance of publicly owned hotel enterprises in Kenya. We argue that a possible reason for these mixed findings could be that prior studies do not distinguish between different types of resources (internal vs. external) used by tourism firms despite significant differences in their nature and impact on firm performance.

\section{Internal Resource Orientation}

The internal resources orientation refers to an organization's internal competencies to be detected and used to achieve innovative outcomes (Baker \& Nelson, 2005). Specifically, based on empirical evidence, Baker and Nelson (2005) show that whenever the resources are combined for a new purpose, it leads to new and advanced services from existing resources. Salunke et al. (2013) also point out that project-oriented firms can recombine and employ available resources with the help of entrepreneurial skills to achieve service innovation, which enhances their competitive advantage. This is termed "collective bricolage", wherein the organizations engage with each other and collaborate in communication and learning to mutually form the growing bricolage practices (e.g., O’Regan, 2015). As an example of 
internal resource orientation in tourism context, Sørensen \& Jensen (2019) show that including front-line employees in innovation processes may help tourism companies to go beyond service production and create new experiential value. However, this would require suitable organizational structures and mind-sets to support front-line employees' efforts and to encourage their creativity through specific activities, such as facilitated workshops.

\section{External Resource Orientation}

The collaboration of a firm with its external partners, which involves interactions and mutual exchange of their assets (Faems et al., 2005), forms the basis of external resource orientation of a firm. Vargo and Lusch (2008) define external resource orientation using their service-dominant (S-D) logic wherein all the co-creators of services are involved in mutual processes to bring out innovation in the customer offerings (Font et al., 2021). Many firms in the tourism sector display external resource orientation by looking beyond their internal core competencies to tap into external collaborations and inter-organizational partnership, which allows them to share tangible and intangible resources with complementary objectives and to reap profits from such efforts (El-Kassar \& Singh, 2019; Wood \& Stierand, 2017).

\section{Value Co-creation in Tourism}

Value co-creation refers to "the act of creating products and services through the collaboration between customers, managers, employees and other beneficiaries of the company" to create value for everyone involved (Ramaswamy \& Gouillart, 2010, p. 4). The concept of value co-creation has established a new relationship between producers and consumers in the services sector (Jaakkola et al., 2015). In the tourism industry, value cocreation is essential to create different kinds of experiences (Sugathan \& Ranjan, 2019; Buhalis \& Foerste, 2015; Campos et al., 2018). In such a value co-creation process, the tourists are the co-creators of value (Hwang \& Han, 2014). In fact, at times, they are even the 
sole creators of value (Rihova et al., 2018), contributing significantly to the sustainable growth of the tourism organization (Tuan et al., 2019).

Organizations design value co-creation strategies by involving their customers to personalize services to maintain long-term personal relationships and gain competitive advantages (Prahalad \& Ramaswamy, 2004). Notably, this happens frequently with tourism organizations. In fact, for these organizations, the value co-creation process starts before, is sustained during, and even after the travel. Collaborative value co-creation effectively offers an integrated tourism service to 'holistically' understand the tourists' experience (Räikkönen and Honkanen, 2013). However, most studies in tourism area explore value co-creation either from a theoretical or an applied perspective (Campos et al., 2017; Prebensen \& Xie, 2017; Sugathan \& Ranjan, 2019), leading to calls for more empirical research in tourism context.

\section{Service Innovation}

Service innovation is defined as a multidimensional construct, that may involve 'radical', 'Ad-hoc', 'improvement', 'incremental', 'recombinative', 'exploratory', 'exploitative', 'supportive', and 'interactive' innovations (Gregor \& Hevner, 2017). In today’s fast-paced world, organizations must stay on top by constant innovation to enhance their appeal to their customers. Thus, service innovation results in value creation and it may boost market performance, customer value, and efficiency (Satta et al., 2019; Sørensen \& Jensen, 2019; Troisi et al., 2019; Vo Thanh et al., 2020) across diverse service settings (Pinto et al., 2017; Sørensen \& Jensen, 2019), including tourism context (e.g., Cortese et al., 2019). Most organizations practice 'incremental service innovation', which involves minor improvements in their products, services or processes to achieve marginally better results (Myhren et al., 2018). By contrast, 'radical service innovation' represents primary changes in their offerings that result in dramatic improvements in performance (Martínez-Pérez et al., 2019). 
In other words, radical service innovation aggrandizes existing systems, procedures or products and replaces them with newer ones, thereby providing higher customer benefits (Wallin \& Fuglsang, 2017). However, globalization has led to deregulation and increased competition in the tourism sector, and the tourist profile has also changed. Tourists have become more experienced and informed. Information and Communication Technologies (ICT) is probably 'the strongest driving force for changes in tourism' (Troisi et al., 2019). Therefore, tourism organizations must do something creative, innovative, and cost completive to remain in the competition. However, there is a paucity of studies that separate the impact of the two forms of service innovation, namely, radical and incremental innovation. In this study, we focus on both, incremental and radical service innovations, due to their wide usage under diverse tourism settings.

\section{Tourist Experience}

Tourism service providers offer a wide range of products and services, which leads to a unique experience, including innovative service encounters (Sørensen \& Jensen, 2019), new technologies for smart tourism (Giaccone \& Bonacini, 2019), and smart service ecosystems (Troisi et al., 2019). Tourist experiences are generally the outcome of visits, which impact the image of destinations. Indeed, destination marketing organizations (DMOs) aim to maintain and enhance positive and memorable tourist experiences, which deliver a practical outcome (Neuhofer, 2016; Prebensen et al., 2018). Tourism firms and their customers co-create the value of the experience not just by their presence but also by considering the more extensive physical and social context of what is being experienced (Hoarau-Heemstra \& Eide, 2019; Hoarau \& Kline, 2014). Considering the journey of a tourist in all its phases, including before, during, and after the visit to a tourist destination, tourist experience is developed at all the contact points during this interactive process (Majboub, 2014; Neuhofer, 2016; Oxenswardh, 2018; Prebensen et al., 2018). The tourist experiences are further connected to 
tourists through various stakeholders such as other tourists, governments, service providers, and local communities. Hence, destination marketers and relationship managers of tourism companies need to concentrate on the tourist experience of customers entirely instead of focusing on just the core services (Jaakkola et al., 2015).

\section{Conceptual Model and Hypotheses Development}

\section{Resource Orientation and Service Innovation}

Novel services are offered based on the firms' resource orientation as part of the business strategy as service employees and resources help bring out a wide array of distinguished services (O'Regan, 2015). The new services are the outcome of innovations, and that new competencies and skills are formed together with the firm's existing resources. This implies that the firms have to create exclusive, matchless, valuable, and new competencies to gear up their growth and help stay highly competitive (Baker \& Nelson 2005). Radical innovations bring uniqueness into the products, and processes (Martínez-Pérez et al., 2018). Radical innovations can be brought by combining and applying creative and unique ideas and knowledge distant from the firm's knowledge base. Contrary to this, incremental innovations are likely to be determined by exploiting knowledge domains close to the tourist firm (Souto, 2015). However, irrespective of these differences between the two types of innovation, we expect both of these to be positively influenced by internal resource orientation, as follows:

H1: Internal resource orientation positively affects a) incremental and b) radical innovation in tourism services.

Firms rely on external resources to develop or create new ideas (Faems et al., 2005). Since scarcity of resources is inevitable while offering services, firms have to collaborate with other external resources through networking (Äyväri \& Jyrämä, 2017). Kim and Lui (2015) explore how firms can get the right to use resources that are not internal to the 
organization and aid innovation through network collaborators. Past research shows a collective impact of external resource orientation on innovation in tourism context, such as green innovation and sustainable tourism (Satta et al., 2019) and the management practices of small and medium tourism companies (Set et al., 2017). Hence, we hypothesize as follows:

H2: External resource orientation positively influence a) incremental and b) radical innovation in tourism services.

\section{Resource Orientation and Value Co-creation}

A firm's ability to gather resources is a crucial determinant of its value co-creation (Plé, 2016), as suggested in the seminal work by Vargo and Lusch (2008, p.3), who note that "organizations exist to integrate and transform micro-specialized competencies into complex services that are demanded in the marketplace". Therefore, resource facilitators are associated with integrators in the value creation process (Vargo \& Lusch, 2008). Similarly, studies show that services are created by integrating and applying resources with the employees closely involved in the value co-creation process. Value co-creation is based on simultaneous production and consumption and it implies that it is impossible to deliver services without the active involvement of customers. Regarding resource orientation integrated with value cocreation, it is clear that most organizations accurately integrate and use resources by forming a team of customers and resource partners (Zeithaml et al., 2009). Thus, value co-creation can be a tactical strategy to create new services with a combination of various resources, such as information and communication technologies - ICT (Troisi et al., 2019). Drawing on the above, the following hypotheses are formulated:

H3: a) Internal and b) external resource orientations positively influence value co-creation.

\section{Value Co-creation and Service Innovation}

Research on service innovation shows that organizations have to work in collaboration 
with various alliances that are strategic or other distribution forms to stay ahead of their competition and to remain relevant in the marketplace (Goossen, 2016). For example, value co-creation positively influences service innovation depending upon the collaborative partner's compatibility and strength of business relations (Santos-Vijande et al., 2018). Firms also undertake various collaborations such as engaging services of consultancies, collaborating with universities, and developing research and development (R\&D) cells as partners to increase their ability to cope with the competition and to gain a competitive advantage through innovation (Jaakkola et al., 2015; Vargo \& Lusch, 2017). Therefore, H4: Value co-creation positively influences a) incremental and b) radical innovations in tourism services.

Service innovation can be understood as changing the customers' role and value-creation processes (Vargo \& Lusch, 2017). Innovation manifests as a change in the company's competencies, the competencies of the customer, the prerequisites of the offering, or what the customer co-creates. Both of these conceptualizations of service innovation are independent of the offering's degree of tangibility and focus on the role and value-creational processes of the customer. Additionally, previous research also confirms the positive impact of value cocreation and resource collaboration on the effectiveness of innovative strategies (Vespestad \& Gressnes, 2021). Accordingly, we hypothesize as follows:

H5: Value co-creation mediates the positive influence of internal resource orientation on a) incremental and b) radical innovations in tourism services.

Moeller (2008) argues that resource integration requires incorporating an actor's resources into the company's resources, while Vargo and Lusch (2008) also confirm that resource integration is not a unidirectional process but is a multidirectional process with a many-to-many view. Within this view, Polese et al. (2018) show that the primary mechanism 
of value co-creation process is resource integration from several actors as per their needs, expectations, and capabilities. In this context, Sun et al. (2020) show that value co-creation mediates the impact of corporate social responsibility on customer loyalty. Similarly, Yousaf (2021) finds green value co-creation as a mediator between green dynamic capability and green innovation. Accordingly, we argue that the resource orientation of tourist operators would need to result in value co-creation with their customers in order to full capitalize their impact on their ability to adopt service innovations. Accordingly, we hypothesize as follows:

H6: Value co-creation mediates the positive influence of external resource orientation on a) incremental and b) radical innovation in tourism services.

\section{Service Innovation and Tourist Experience}

In this era of globalization, innovation has emerged as the critical determinant of sustaining the competitiveness of tourist destinations (Hjalager, 2014; Satta et al., 2019; Sørensen \& Jensen, 2019). Past research on the role of innovation in tourism explores the tourism firms' collaboration with their customers for innovation and value co-creation (Carbonell \& Rodríguez-Escudero, 2014; Greer \& Lei, 2012). Generally, innovation has become critical as the nature of tourism services has undergone a sea change, and the complexity of the services has increased. Service providers have made some efforts to optimize resources to create experiences for tourists and tourists, which have resulted in positive tourist evaluations (Artal-Tur, 2019; Hjalager, 2014; Satta et al., 2019; Sørensen \& Jensen, 2019). Accordingly, we hypothesize a positive influence of incremental and radical innovations of tourism services on the co-creative tourist experience, as follows:

H7: a) Incremental and b) radical innovations positively influences tourist experiences.

Tourist Experience, Brand Advocacy, and Revisit Intentions

Brand advocacy is an indispensable tool widely used in marketing by successful tourist 
firms due to its positive impact on consumer-brand identification, customer satisfaction, brand loyalty, and re-purchase intention (Kankam-Kwarteng et al., 2021). For example, positive tourist experiences encourage tourists to share those with others, thus helping promote and build trust in the brand (Kumar \& Kaushik, 2020). Thus, 'brand advocacy' serves as a vital cog, via positive word of mouth, through reviews and feedback shared online and offline (Hudson et al., 2015). Brand advocacy also helps generate demand, increase sales, ward off competition, and retain profitable customers (Bilro et al., 2019) as well as improve customer-based brand equity (CBBE), customer engagement (CE), brand loyalty, brand engagement, and emotional attachment (Bhati et al., 2020).

Similarly, tourists' revisit intentions ensure an enduring success of the tourism destination and increases the revenues for the tourist firm (Prayag et al., 2021). The revisit intentions indicate the visitor's desire to return to the same place (Wu et al., 2017). We argue that when tourists have a pleasant experience of services from their service providers through various channels, it may lead to brand advocacy and enhance their revisit intentions in future. In other words, when tourists receive a good experience, they may feel attached with the tourism brand and the destination, which in turn would lead to brand advocacy and revisit intentions. Accordingly, we offer our final hypotheses, as follows:

H8: Tourist experience positively influences a) brand advocacy and b) revisit intentions.

Figure 1 shows the conceptual model with all the hypotheses.

$<$ Insert figure 1 about here $>$

\section{Method}

Sampling and Data Collection

Tourism has been one of the growing sectors in the Indian economy, as reflected by its $6.8 \%$ contribution to the GDP and 8\% to total employment in 2019 (Dash \& Sharma, 2021). 
The Indian tourism sector is predicted to grow at an annual rate of $6.9 \%$ to $\$ 460$ billion by 2028, which would be $9.9 \%$ of GDP. Therefore, it is not surprising to see Indian tourism operators trying to develop creative and innovative offerings to meet the tourists' changing needs (O’Regan, 2015; Satta et al., 2019), which makes India an appropriate setting for this study. The sample includes the top ten tourism companies in India and others established at least five years before this study to ensure they had sufficient experience in the Indian tourism market. Moreover, only those firms were selected that had provided a new service or service delivery system to their clients at least once within the last three years.

We collected data from two matching sets of respondents; first, the managers of Indian tourist companies, and second, the tourists who used the services provided by these tourist companies. Only those tourist managers were selected who had worked for at least five years as a manager in the tourism industry and were involved in new service development process. Finally, a matching sample of tourists was selected based on their actual experience with one of the innovative services offered by each tourist company included in the sample. We approached 330 respondents meeting the above criteria and received 191 completed questionnaires (59\% response), which meets the minimum sample size (five times the number of indicators), recommended by Hair et al. (2017). Table 1 shows the sample profiles.

$<$ Insert table 1 about here $>$

\section{Measures}

A structured questionnaire with two parts was used to collect the data. The first part was completed by the tourist managers for resource orientation, value co-creation, and service innovation, and the second by the tourists for tourist experience, brand advocacy, and revisit intentions. All the constructs were operationalized using items adapted from existing wellestablished scales. For example, internal resource orientation was measured with five items 
adapted from Baker and Nelson (2005), and external resource orientation with four items adapted from Faems et al. (2005). Similarly, five items each for incremental and radical service innovation were adapted from Avlonitis et al. (2001). Tourist experience was measured with the 14-item customer experience scale (Yi \& Gong, 2013) and value cocreation with four-item scale adapted from Zhang and Chen (2008). Finally, brand advocacy was measured with two items adapted from Brown et al. (2005) and Ahearne et al. (2005) and revisit intentions with two items taken from Stokburger-Sauer (2011). All the scales use a 7point Likert scale $(1=$ strongly disagree and $7=$ strongly agree $)$. Table 2 shows all the scale items and their psychometric properties.

$<$ Insert table 2 about here $>$

\section{Data Analysis and Results}

Partial least square structural equation modeling (PLS-SEM) technique with Smart PLS-3 was used to analyze the data as it is appropriate for relatively smaller sample sizes and where the main aim is to test the predictive power of the conceptual model and to explain the variance in the outcome variables (Hair et al., 2017). We used bootstrapping with 5,000 subsamples (Hair et al., 2017) and also tested the reliability and validity of all the scales, using Cronbach's alpha, composite reliability (CR), and average variance extracted (AVE), as shown in Table 3. All the outer loadings are higher than 0.60, which along with Cronbach's alpha and CR values higher than 0.70 and the AVE values are higher than 0.50 , confirms convergent validity (Hair et al., 2010). Multicollinearity is not a problem in the study as all the variance inflation factor (VIF) values are less than 5. Finally, we assessed discriminant validity using the Fornell-Larcker criterion and cross-loading of all the construct items. As shown in Table 4, the square roots of the AVE of each latent construct are higher than its correlations with all the other constructs (Fornell \& Larcker, 1981). 
$<$ Insert tables $3 \& 4$ about here $>$

\section{Common Method Bias}

We used a survey-based method to collect responses from two different sources (managers and tourists) to study the cause-and-effect relationships among the constructs included in this study, which helps reduce the risk of common method bias (CMB) (Mackenzie \& Podsakoff, 2012). In addition, to ensure the impact of CMB in this study, we used Harman's single factor test (Podsakoff \& Organ, 1986) to assess CMB. The result reveals that 32.43 percent of variance had been explained by a single factor, representing less than 50 percent, thus CMB may not be a major concern in this study.

\section{Hypotheses Testing}

Next, we tested all the hypotheses. First, internal resource orientation does not have significant effects on both, incremental $(\beta=0.064, p>.05)$ and radical $(\beta=0.189, p>.05)$ innovations, thus $\mathrm{H} 1 \mathrm{a}$ and $\mathrm{H} 1 \mathrm{~b}$ are not supported. Next, external resource orientation has significant positive effects on both, incremental $(\beta=0.336, p<.01)$ and radical $(\beta=0.212, p$ $<.05)$ innovations, thus $\mathrm{H} 2 \mathrm{a}$ and $\mathrm{H} 2 \mathrm{~b}$ are supported. Next, both internal $(\beta=0.576, p<.001)$ and external $(\beta=0.811, p<.001)$ resource orientation have significant positive effects on value co-creation, thus $\mathrm{H} 3 \mathrm{a}$ and $\mathrm{H} 3 \mathrm{~b}$ are also supported. Similarly, value co-creation has positive effects on both incremental $(\beta=0.467, p>.001)$ and radical $(\beta=0.462, p<.001)$ innovations, supporting $\mathrm{H} 4 \mathrm{a}$ and $\mathrm{H} 4 \mathrm{~b}$, respectively. Next, both incremental $(\beta=0.283, p<$ $.05)$ and radical $(\beta=0.303, p<.05)$ innovation also positively influence tourist experience, thus $\mathrm{H} 7 \mathrm{a}$ and $\mathrm{H} 7 \mathrm{~b}$ are supported. Finally, tourist experience has a significant impact on both brand advocacy $(\beta=0.533, \mathrm{p}<.001)$ and revisit intentions $(\beta=0.483, \mathrm{p}<.001)$ of the tourists, thus $\mathrm{H} 8 \mathrm{a}$ and $\mathrm{H} 8 \mathrm{~b}$ are also supported. Table 5 shows these results.

Next, we tested our hypotheses about mediating role of value co-creation by calculating 
the 'Variance Accounted For' (VAF), which defined as the ratio of indirect effect to the total effect (Hair et al., 2017). As shown in Table 6, value co-creation partially mediates the impact of internal resource orientation on both incremental and radical innovation but it does not mediate the impact of external resource orientation on both types of innovation. Thus, $\mathrm{H} 5 \mathrm{a}$ and $\mathrm{H} 5 \mathrm{~b}$ are partially supported, whereas H6a and H6b are not supported.

$<$ Insert tables $5 \& 6$ about here $>$

\section{Discussion}

The objective of this study was to examine the focal role of value co-creation in the process by which internal and external resource orientations of tourism companies impact their incremental and radical service innovations, which translates into tourist experience, brand advocacy and revisit intentions. The results provide empirical support to most of the hypothesized relationships by taking into account both direct and indirect effects of resource orientations and value co-creation on service innovations and the subsequent effect of service innovation on tourist experience and important tourist outcomes. This study is built on the premise that service innovations are more likely to be successful when organizations tend to be both market- and resource-oriented (Baker \& Nelson, 2005). Although the linkages between components of organizational structure and service innovation have been studied in other contexts, such as financial services (Jansen et al., 2006), this study is the first attempt to empirically link the firms' resources and value co-creation with service innovation in the tourism context, using tourist experience and other important tourist outcomes.

Resource integration perspective based on S-D logic assumes that customers possess some value. Thus, marketers should co-create value with them more effectively (Vargo \& Lusch, 2008). The current study demonstrates that it is not enough to design an effective coordination mechanism and customer-led market-oriented strategy for innovative services. 
Instead, firms require a blended approach with an optimum resource-oriented view (Zhang \& Chen, 2008; Roy et al., 2017). Accordingly, this study uses a novel conceptualization of resource-oriented behavior comprising its two dimensions (internal and external resource orientation) along with a value co-creation mechanism to analyze its effects on both types of service innovation (radical and incremental) in the tourism industry.

This study examines the direct and indirect effects of both the internal and external resource orientations on service innovations through value co-creation. Of the two types of resource orientation, we find that the direct impact of external resource orientation on both types of service innovation is stronger than for internal resource orientation. These results show that tourist firms may not find it enough to use their internal resources in order to cocreate tourist experiences and they would need to combine these with external resources by collaborating with other stakeholders involved in creating and launching service innovations, such as customers, channel partners, local authorities, policy makers etc. Interestingly, we also find that value co-creation fully mediates the impact of internal resource orientation on both incremental and radical service innovation. By contrast, value co-creation does not mediate the impact of external resource orientation on both incremental and radical service innovation. Hence, it is clear that external resource orientation (i.e., collaboration with educational and research institutes) can aid tourist firms to directly improve their existing services and undertake breakthrough innovations. However, they would need to leverage their internal resources to co-create value before they can benefit from service innovation.

\section{Theoretical Contributions}

This paper makes useful theoretical contributions to the tourism literature. First, this study integrates the RBV (Barney, 2001) and S-D logic (Vargo \& Lusch, 2004) with value cocreation (Prahalad \& Ramaswamy, 2004) to delineate the process by which tourist firms' resource orientations and value co-creation efforts impact their service innovation and tourist 
experience, which in turn influence important tourist outcomes. Second, we incorporate two types of resource orientations with service innovations to investigate the mediating role of value co-creation in their relationship with each other. Our results show significant differences in the way internal and external resources influence tourist experience, wherein compared to external resources, internal resources do not seem to be enough to directly impact tourist experience and other outcomes. These findings are in line with past research that recommends tourism firms to take lead in resource orientation by implementing and monitoring their internal resources to co-create value in order to drive service innovations (Neuhofer, 2016). In other words, the tourism industry would find it useful to help their employees and tourists to co-create value in order to unlock the full potential of their internal resources, whereas their external resources may have a direct impact on their innovations. Finally, this study also contributes to the growing literature on tourism in the emerging markets (e.g., Hollebeek \& Andreassen, 2018), by offering valuable insights into how Indian tourist managers leverage their internal and external resources to co-create value and to deliver their service innovations, in order to improve tourist experience and outcomes.

\section{Managerial Implications}

Besides its theoretical contributions, this study also has many managerial implications. First, our results highlight that tourism firms need to leverage both internal and external resources in order to successfully co-create value with their customers and also implement their service innovations. In other words, these firms may be able to create new services by combining their internal and external resources to focus on radical innovation rather than simply relying on incremental innovation. We expect this would help them enhance their performance continuously and achieve sustainable growth for their tourism business. Second, this study would help service managers realize the importance of considering organizational factors, such as internal and external resources, when developing their service innovations 
and strategies to manage tourist experiences. Our findings recommend an integrated approach that incorporates both market-oriented and resource-oriented views to undertake service innovation to help improve the performance of the tourism service providers. Importantly, to create a win-win situation, tourism companies would need to take the lead to implement the latest technological changes to bring innovation in services (Neuhofer, 2016).

Third, we show that tourism firms, especially in emerging markets like India, may need to adopt an adjusted approach to developing new services in the tourism sector because both types of innovations (incremental and radical) are essential to improve their performance and competitiveness. For example, while incremental service innovations (i.e., modifications, repositioning, and line extensions) as a strategic choice would enable tourism organizations to effectively deal with market volatilities and uncertainties and be better prepared to adapt to the changing business environment, this may not be enough to face the long-term challenges or surprises like the Covid-19 pandemic. Hence, these firms also need to use radical service innovations to prepare themselves for any unforeseeable emergencies and the cataclysmic changes in the industry that may require them to adapt their business models very quickly. Overall, the results from this study indicate that a balanced approach using both incremental and radical innovations may help tourism operators to reap maximum benefits.

Fourth, the results from this study also indicate that a proactive customer-oriented approach with a clear understanding of the customers' changing tourist expectations may enable tourism organizations to deliver value through service innovations. For instance, tourism organizations may ask customers to plan their itineraries using appropriate software tools on their websites or mobile applications. This would effectively reduce human errors, thereby making service delivery more efficient and convenient for the tourists. Tourist organizations should also not restrict themselves to their existing resources and may explore collaborative opportunities, with new resource partners. For instance, tourism organizations 
could look to collaborate with consultancy services or educational and research institutes to gain new market knowledge and understand the immense market potential and trends.

Fifth, despite innovation being a critical determinant of marketplace success, investments made by Indian service companies in their research and development (R\&D) activities have been at a relatively lower level compared to international standards (Malik et al., 2021). Hence, enhanced R\&D efforts are required to check service feasibility at the introduction stage to prevent serious service failures. Additionally, organizations also need to explore their intangible resources, such as their employees' tactical knowledge, skills, and competencies. These 'intangible' resources may be combined with existing physical assets such as machinery or equipment to make them more competitive and sustainable in the long run.

Sixth, this study also encourages tourism organizations to form informal and close-knitted social relations, as it could be an effective coordination mechanism to derive maximum benefits by leveraging external resources for value co-creation. For instance, increased connectedness among employees (i.e., easy accessibility, frequent interactions, and sharing common goals) could have a significantly positive impact on radical and incremental service innovation (Hardy \& Robards, 2015). Thus, managers of tourism organizations could direct their employees to share common goals to increase their capabilities to pursue both types of innovations simultaneously. Finally, employees' views could also be elicited through open forums, informal meetings, and discussions; participative employees could be rewarded for their insights. The results suggest a significant role of value co-creation in developing new services. In a globalized world, businesses cannot work in isolation and they need to find ways to collaborate and partner with other players in the related industries (e.g., education, hospitality, health and wellness, food and nutrition, and travel) to enhance the brand value. 


\section{Limitation and Future Research}

This study has a few limitations that future research may address. First, we included two types of resource orientations as drivers of value co-creation in our conceptual model but there may be many other constructs that could also be relevant in this context. Hence, future studies may identify additional constructs to develop more comprehensive conceptual models to extend our ideas presented in this paper. Second, although we discuss innovation in this paper, we do not focus on the adoption of new technologies or the training that customers and employees may need to adopt these technologies. Future research may address this issue in more detail. Third, we included incremental and radical innovation in this study to keep our conceptual model parsimonious but there are other types of innovation, such as architectural and disruptive innovation, that may also play a role in this context. Further research could incorporate all four types of innovation or a combination of these types of innovation. Finally, resource-based view not only deals with firm resource but also focuses on how tourists may integrate their own resources (e.g., time, money, or effort) when co-creating their tourist experiences. Future research may study the role of resource integration from the tourist's perspective and its combined impact with the tourism firms' resource integration.

\section{References}

Ahearne, M., Bhattacharya, C. B., \& Gruen, T. (2005). Antecedents and consequences of customer company identification: expanding the role of relationship marketing. Journal of Applied Psychology, 90(3), 574-585.

Artal-Tur, A. (2019). New technologies and innovation in the tourism and hospitality sectors. Tourism Analysis, 24(1), 1-79.

Avlonitis, G. J., Papastathopoulou, P. G., \& Gounaris, S. P. (2001). An empirically based typology of product innovativeness for new financial services: Success and failure scenarios. Journal of Product Innovation Management, 18(5), 324-342. 
Äyväri, A., \& Jyrämä, A. (2017). Rethinking value proposition tools for living labs. Journal of Service Theory and Practice.

Barney, J. B. (2001). Resource-based theories of competitive advantage: A ten-year retrospective on the resource-based view. Journal of Management, 27(6), 643-650.

Baker, T., \& Nelson, R.E. (2005). Creating something from nothing: Resource construction through entrepreneurial bricolage. Administrative Science Quarterly, 50(3), 329-366.

Bhat, D. A. R., \& Sharma, V. (2021). Enabling service innovation and firm performance: the role of co-creation and technological innovation in the hospitality industry. Technology Analysis \& Strategic Management, 1-13.

Bhati, R. and Verma, H. V. (2020), "Antecedents of customer brand advocacy: a metaanalysis of the empirical evidence", Journal of Research in Interactive Marketing, 14(2), 153-172.

Bilro, R. G., Loureiro, S. M. C., \& Guerreiro, J. (2019). Exploring online customer engagement with hospitality products and its relationship with involvement, emotional states, experience and brand advocacy. Journal of Hospitality Marketing \& Management, $28(2), 147-171$.

Brown, J., Broderick, A. J. and Lee, N. (2007), "Word of mouth communication within online communities: Conceptualizing the online social network", Journal of Interactive Marketing, Vol. 21, No. 3, pp. 2-20.

Buhalis, D., \& Foerste, M. (2015). SoCoMo marketing for travel and tourism: Empowering co-creation of value. Journal of Destination Marketing \& Management, 4(3), 151-161.

Campos, A. C., Mendes, J., do Valle, P. O., \& Scott, N. (2017). Co-creating animal-based tourist experiences: Attention, involvement and memorability. Tourism Management, 63, 100-114.

Campos, A. C., Mendes, J., Valle, P. O. D., \& Scott, N. (2018). Co-creation of tourist 
experiences: A literature review. Current Issues in Tourism, 21(4), 369-400.

Carbonell, P., \& Rodriguez-Escudero, A. I. (2014). Antecedents and consequences of using information from customers involved in new service development. Journal of Business \& Industrial Marketing.

Casais, B., Fernandes, J., \& Sarmento, M. (2020). Tourism innovation through relationship marketing and value co-creation: A study on peer-to-peer online platforms for sharing accommodation. Journal of Hospitality and Tourism Management, 42, 51-57.

Cavalheiro, M. B., Joia, L. A., \& Cavalheiro, G. M. D. C. (2020). Towards a smart tourism destination development model: Promoting environmental, economic, socio-cultural and political values. Tourism Planning \& Development, 17(3), 237-259.

Cortese, D., Cantino, V., Solazzo, G., \& Fassio, F. (2019). From triple bottom line to circular monitoring in evaluation of food tourism events. Tourism Analysis, 24(3), 281-289.

Daglis, T., \& Katsikogianni, M. A. (2021). The repercussions of COVID-19 on the stock market of the Tourism industry. Tourism Analysis, DOI: $10.3727 / 108354221 X 16307183274967$.

Dash, S. B., \& Sharma, P. (2021). Reviving Indian Tourism amid the Covid-19 pandemic: Challenges and workable solutions. Journal of Destination Marketing \& Management, 22,100648 .

De Bernardi, P., Bertello, A., \& Shams, S. M. (2019). Logics hindering digital transformation in cultural heritage strategic management: An exploratory case study. Tourism Analysis, 24(3), 315-327.

Del Chiappa, G., \& Baggio, R. (2015). Knowledge transfer in smart tourism destinations: Analyzing the effects of a network structure. Journal of Destination Marketing \& Management, 4(3), 145-150.

El-Kassar, A. N., \& Singh, S. K. (2019). Green innovation and organizational performance: 
the influence of big data and the moderating role of management commitment and HR practices. Technological Forecasting and Social Change, 144, 483-498.

Evans, N. G. (2016). Sustainable competitive advantage in tourism organizations: A strategic model applying service dominant logic and tourism's defining characteristics. Tourism Management Perspectives, 18, 14-25.

Faems, D., Van Looy, B., \& Debackere, K. (2005). Interorganizational collaboration and innovation: Toward a portfolio approach. Journal of Product Innovation Management, $22(3), 238-250$.

Font, X., English, R., Gkritzali, A., \& Tian, W. S. (2021). Value co-creation in sustainable tourism: A service-dominant logic approach. Tourism Management, 82, 104200.

Fornell, C., \& Larcker, D. F. (1981). Structural equation models with unobservable variables and measurement error: Algebra and statistics.

Giaccone, S. C., \& Bonacini, E. (2019). New technologies in smart tourism development: the\# iziTRAVELSicilia experience. Tourism Analysis, 24(3), 341-354.

Goossen, M. C. (2016). Interorganizational collaboration, intraorganizational networks, and firm innovation. Academy of Management Proceedings, 2015(1), 10595-10595.

Greer, C. R., \& Lei, D. (2012). Collaborative innovation with customers: A review of the literature and suggestions for future research. International Journal of Management Reviews, 14(1), 63-84.

Gregor, S., \& R. Hevner, A. (2017). The Knowledge Innovation Matrix (KIM): A Clarifying Lens for Innovation. Informing Science: The International Journal of an Emerging Transdiscipline.

Hair, J. F. J., Black, B., Babin, B., Anderson, R. E., \& Tatham, R. L. (2010), Multivariate Data Analysis: A Global Perspective, Pearson Education Inc., Upper Saddle River, NJ. Hair, J. F. J., Hult, G. T. M., Ringle, C. M. and Sarstedt, M. (2017), A Primer on Partial Least 
Squares Structural Equation Modeling (PLS-SEM), 2nd ed., Sage, Thousand Oaks, CA.

Hardy, A., \& Robards, B. (2015). The ties that bind: Exploring the relevance of neotribal theory to tourism. Tourism Analysis, 20(4), 443-454.

Hjalager, A. M. (2014). Who controls tourism innovation policy? The case of rural tourism. Tourism Analysis, 19(4), 401-412.

Hoarau, H., \& Kline, C. (2014). Science and industry: Sharing knowledge for innovation. Annals of Tourism Research, 46, 44-61.

Hoarau-Heemstra, H., \& Eide, D. (2019). Values and concern: Drivers of innovation in experience-based tourism. Tourism and Hospitality Research, 19(1), 15-26.

Hollebeek, L. D., \& Andreassen, T. W. (2018). The SD logic-informed "hamburger" model of service innovation and its implications for engagement and value. Journal of Services Marketing.

Hudson, S., Roth, M. S., Madden, T. J., \& Hudson, R. (2015). The effects of social media on emotions, brand relationship quality, and word of mouth: An empirical study of music festival attendees. Tourism Management, 47, 68-76.

Hwang, J., \& Han, H. (2014). Examining strategies for maximizing and utilizing brand prestige in the luxury cruise industry. Tourism Management, 40, 244-259.

Jaakkola, E., Helkkula, A., \& Aarikka-Stenroos, L. (2015). Service experience co-creation: conceptualization, implications, and future research directions. Journal of Service Management, 26(2), 182-205.

Jansen, J. J., Van Den Bosch, F. A., \& Volberda, H. W. (2006). Exploratory innovation, exploitative innovation, and performance: Effects of organizational antecedents and environmental moderators. Management Science, 52(11), 1661-1674.

Kankam-Kwarteng, C., Amo, F., Osei, F., \& Bediako, D. O. (2021). Service Innovation and Service Quality Effects on Marketing Performance of SMEs. Innovation, 2(1), 1-10. 
Kim, Y., \& Lui, S. S. (2015). The impacts of external network and business group on innovation: Do the types of innovation matter?. Journal of Business Research, 68(9), 1964-1973.

Kumar, V., \& Kaushik, A. K. (2020). Does experience affect engagement? Role of destination brand engagement in developing brand advocacy and revisit intentions. Journal of Travel \& Tourism Marketing, 37(3), 332-346.

Lentu, L. M., Khayiya, R., \& Ondigi, A. (2021). Influence of strategic orientation on performance of publicly owned hotel enterprises in Kenya. European Journal of Hospitality and Tourism Research, 9(1), 37-57.

Line, N. D., \& Runyan, R. C. (2014). Destination marketing and the service-dominant logic: A resource-based operationalization of strategic marketing assets. Tourism Management, $43,91-102$.

MacKenzie, S. B., \& Podsakoff, P. M. (2012). Common method bias in marketing: Causes, mechanisms, and procedural remedies. Journal of retailing, 88(4), 542-555.

Majboub, W. (2014). Co-creation of Value or Co-creation of Experience? Interrogations in the Field of Cultural Tourism. International Journal of Safety and Security in Tourism, 7(7), 12-31.

Malik, A., Mahadevan, J., Sharma, P., \& Nguyen, T. M. (2021). Masking, claiming and preventing innovation in cross-border B2B relationships: Neo-colonial frameworks of power in global IT industry. Journal of Business Research, 132, 327-339.

Martínez-Pérez, Á., Elche, D., \& García-Villaverde, P. M. (2019). From diversity of interorganizational relationships to radical innovation in tourism destination: The role of knowledge exploration. Journal of Destination Marketing \& Management, 11, 80-88.

Mishra, A., \& Gupta, A. (2019). Effect of hotel green service encounters: Evidence from India. Tourism Analysis, 24(4), 535-541. 
Moeller, S. (2008). Customer integration — a key to an implementation perspective of service provision. Journal of service research, 11(2), 197-210.

Mohammadi, F., Yazdani, H. R., Pour, M. J., \& Soltani, M. (2020). Co-creation in tourism: a systematic mapping study. Tourism Review, 76(2), 305-343.

Myhren, P., Witell, L., Gustafsson, A., \& Gebauer, H. (2018). Incremental and radical open service innovation. Journal of Services Marketing, 32(2), 101-112.

Neuhofer, B. (2016). Value co-creation and co-destruction in connected tourist experiences. In Information and communication technologies in tourism 2016 (pp. 779-792). Springer, Cham.

O’Regan, M. (2015). Methodological bricolage: A journey on the road less traveled in tourism studies. Tourism Analysis, 20(5), 457-467.

Oxenswardh, A. (2018). Processes of value co-creation at a tourist accommodation. Quality Innovation Prosperity, 22(3), 36-54.

Phi, G., \& Dredge, D. (2019). Critical issues in tourism co-creation. Tourism Recreation Research, 44(3), 281-283.

Pinto, G. L., Dell'Era, C., Verganti, R., \& Bellini, E. (2017). Innovation strategies in retail services: solutions, experiences and meanings. European Journal of Innovation Management, 20(2), 190-209.

Plé, L. (2016). Studying customers' resource integration by service employees in interactional value co-creation. Journal of Services Marketing, 30(2), 152-164.

Podsakoff, P. M., \& Organ, D. W. (1986). Self-reports in organizational research: Problems and prospects. Journal of management, 12(4), 531-544.

Polese, F., Botti, A., Grimaldi, M., Monda, A., \& Vesci, M. (2018). Social innovation in smart tourism ecosystems: How technology and institutions shape sustainable value cocreation. Sustainability, 10(1), 140. 
Prahalad, C. K., \& Ramaswamy, V. (2004). Co-creation experiences: The next practice in value creation. Journal of Interactive Marketing, 18(3), 5-14.

Prayag, G., Disegna, M., \& Bruwer, J. (2021). Do satisfied cellar door visitors want to revisit? Linking past knowledge and consumption behaviors to satisfaction and intention to return. Tourism Analysis, 26(2-3), 211-224.

Prebensen, N. K., \& Xie, J. (2017). Efficacy of co-creation and mastering on perceived value and satisfaction in tourists' consumption. Tourism Management, 60, 166-176.

Prebensen, N. K., Uysal, M. S., \& Chen, J. S. (2018). Perspectives on Value CreationResource Configuration. In Creating experience value in tourism (pp. 228-237). CABI Publishing Surrey.

Pyke, S., Hartwell, H., Blake, A., \& Hemingway, A. (2016). Exploring well-being as a tourism product resource. Tourism Management, 55, 94-105.

Räikkönen, J., \& Honkanen, A. (2013). Does satisfaction with package tours lead to successful vacation experiences? Journal of Destination Marketing \& Management, 2(2), 108-117.

Ramaswamy, V., \& Gouillart, F. J. (2010). The power of co-creation: Build it with them to boost growth, productivity, and profits. Simon and Schuster.

Rejón-Guardia, F., García-Sastre, M. A., Orfila-Sintes, F., \& Garau-Vadell, J. B. (2020). Virtual reality in tourism: Centennials acceptance. Tourism Analysis, 25(2-3), 335-344.

Rihova, I., Buhalis, D., Gouthro, M. B., \& Moital, M. (2018). Customer-to-customer cocreation practices in tourism: Lessons from Customer-Dominant logic. Tourism Management, 67, 362-375.

Roy, S. K., Balaji, M. S., Soutar, G., \& Jiang, Y. (2020). The antecedents and consequences of value co-creation behaviors in a hotel setting: A two-country study. Cornell Hospitality Quarterly, 61(3), 353-368. 
Roy, S. K., Gruner, R. L., \& Guo, J. (2020). Exploring customer experience, commitment, and engagement behaviours. Journal of Strategic Marketing, https://doi.org/10.1080/0965254X.2019.1642937.

Salunke, S., Weerawardena, J., \& McColl-Kennedy, J. R. (2013). Competing through service innovation: The role of bricolage and entrepreneurship in project-oriented firms. Journal of Business Research, 66(8), 1085-1097.

Santos-Vijande, M. L., López-Sánchez, J. Á., \& Pascual-Fernandez, P. (2018). Co-creation with clients of hotel services: the moderating role of top management support. Current Issues in Tourism, 21(3), 301-327.

Satta, G., Spinelli, R., \& Parola, F. (2019). Is tourism going green? A literature review on green innovation for sustainable tourism. Tourism Analysis, 24(3), 265-280.

Set, K., Agbola, F. W., \& Mahmood, A. (2017). Tourism small and medium enterprise management practices and firm performance. Tourism Analysis, 22(2), 237-245.

Sharma, G. D., Thomas, A., \& Paul, J. (2021). Reviving tourism industry post-COVID-19: A resilience-based framework. Tourism Management Perspectives, 37, 100786.

Sørensen, F., \& Jensen, J. F. (2019). Experience innovation of tourism encounters. Tourism Analysis, 24(1), 55-67.

Souto, J. E. (2015). Business model innovation and business concept innovation as the context of incremental innovation and radical innovation. Tourism Management, 51, 142155.

Stokburger-Sauer, N. E. (2011). The relevance of visitors' nation brand embeddedness and personality congruence for nation brand identification, visit intentions and advocacy. Tourism Management, 32(6), 1282-1289.

Sugathan, P., \& Ranjan, K. R. (2019). Co-creating the tourism experience. Journal of Business Research, 100, 207-217. 
Sun, H., Rabbani, M. R., Ahmad, N., Sial, M. S., Cheng, G., Zia-Ud-Din, M., \& Fu, Q. (2020). CSR, co-creation and green consumer loyalty: Are green banking initiatives important? A moderated mediation approach from an emerging economy. Sustainability, 12(24), 10688.

Troisi, O., Grimaldi, M., \& Monda, A. (2019). Managing smart service ecosystems through technology: how ICTs enable value cocreation. Tourism Analysis, 24(3), 377-393.

Tu, Y., Neuhofer, B., \& Viglia, G. (2018). When co-creation pays: stimulating engagement to increase revenues. International Journal of Contemporary Hospitality Management, 30(4), 2093-2111.

Tuan, L. T., Rajendran, D., Rowley, C., \& Khai, D. C. (2019). Customer value co-creation in the business-to-business tourism context: The roles of corporate social responsibility and customer empowering behaviors. Journal of Hospitality and Tourism Management, 39, 137-149.

Varadarajan, R. (2020). Customer information resources advantage, marketing strategy and business performance: A market resources based view. Industrial Marketing Management, 89, 89-97.

Vargo, S. L., \& Lusch, R. F. (2004). Evolving to a new dominant logic for marketing. Journal of marketing, 68(1), 1-17.

Vargo, S. L., \& Lusch, R. F. (2008). Service-dominant logic: continuing the evolution. Journal of the Academy Of Marketing Science, 36(1), 1-10.

Vargo, S. L., \& Lusch, R. F. (2017). Service-dominant logic 2025. International Journal of Research in Marketing, 34(1), 46-67.

Vespestad, M. K., \& Gressnes, T. (2021). Tourists' willingness to pay for nature-based tourism experiences. Tourism Analysis, 26(2-3), 2-3.

Vo Thanh, T., Seraphin, H., Okumus, F., \& Koseoglu, M. A. (2020). Organizational ambi- 
dexterity in tourism research: A systematic review. Tourism Analysis, 25(1), 137-152.

Wallin, A. J., \& Fuglsang, L. (2017). Service innovations breaking institutionalized rules of health care. Journal of Service Management, 28(5), 972-997.

Wood, R. C., \& Stierand, M. B. (2017). Innovation in hospitality. In Key Concepts in Hospitality Management.

Wu, H. C., Cheng, C. C., \& Hong, W. (2017). An assessment of zoo visitors' revisit intentions. Tourism Analysis, 22(3), 361-375.

Yi, Y., \& Gong, T. (2013). Customer value co-creation behavior: Scale development and validation. Journal of Business Research, 66(9), 1279-1284.

Yousaf, Z. (2021). Go for green: green innovation through green dynamic capabilities: accessing the mediating role of green practices and green value co-creation. Environmental Science and Pollution Research, 28(39), 54863-54875.

Zeithaml, V. A., Bitner, M. O., and Gremler, D. E. (2009). Services Marketing: Integrating Customer Focus across the Firm, McGraw-Hill/Irwin, New York.

Zhang, X., \& Chen, R. (2008). Examining the mechanism of the value co-creation with customers. International Journal of Production Economics, 116(2), 242-250.

Zhong, Y. Y. S., Busser, J., \& Baloglu, S. (2017). A model of memorable tourism experience: The effects on satisfaction, affective commitment, and storytelling. Tourism Analysis, 22(2), 201-217.

Zuñiga-Collazos, A., Harrill, R., Castillo-Palacio, M., \& Padilla-Delgado, L. M. (2020). Negative Effect of Innovation on Organizational Competitiveness on Tourism Companies. Tourism Analysis, 25(4), 455-461. 
Figure 1. Conceptual Model

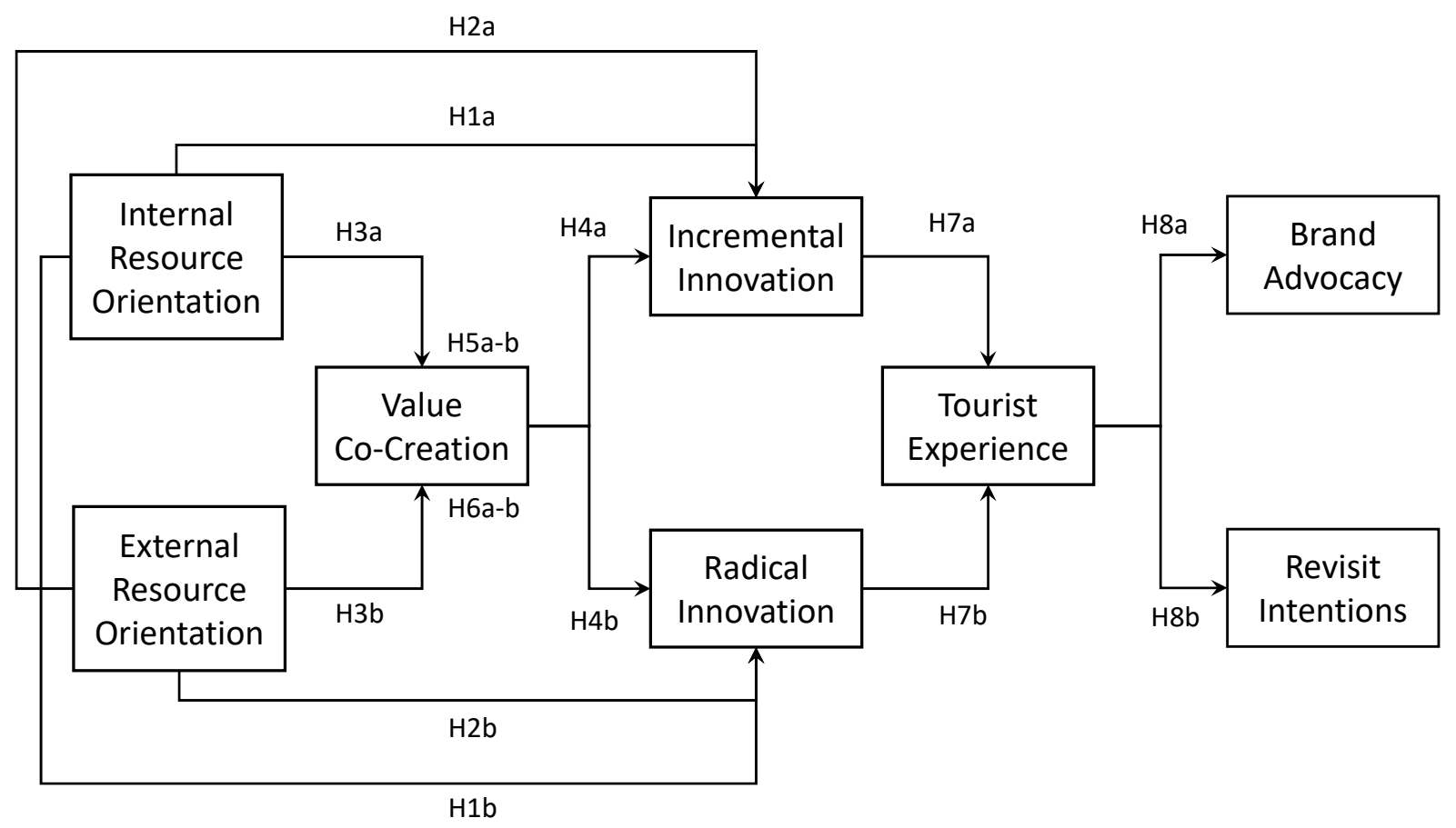


Table 1. Sample profile - Managers and tourists

\begin{tabular}{|c|c|c|c|c|c|}
\hline \multirow{2}{*}{\multicolumn{2}{|c|}{ Characteristics }} & \multicolumn{2}{|c|}{ Managers } & \multicolumn{2}{|c|}{ Tourists } \\
\hline & & \multirow{2}{*}{$\begin{array}{c}\mathbf{N}=\mathbf{1 9 1} \\
173\end{array}$} & \multirow{2}{*}{$\begin{array}{l}\text { \%age } \\
90.57\end{array}$} & \multirow{2}{*}{$\frac{\mathbf{N}=\mathbf{1 9 1}}{104}$} & \multirow{2}{*}{$\begin{array}{l}\text { \%age } \\
54.45\end{array}$} \\
\hline Gender & Male & & & & \\
\hline & Female & 18 & 9.42 & 87 & 45.54 \\
\hline \multirow[t]{4}{*}{ Age } & Below 30 & 04 & 2.04 & 39 & 20.41 \\
\hline & 30 to 45 & 175 & 91.62 & 112 & 58.63 \\
\hline & 45 to 60 & 12 & 6.28 & 40 & 20.94 \\
\hline & Above 60 & Nil & Nil & Nil & Nil \\
\hline \multirow[t]{4}{*}{$\begin{array}{l}\text { Managerial } \\
\text { Role }\end{array}$} & Team Leader & 32 & 16.75 & \multirow{7}{*}{\multicolumn{2}{|c|}{ Not applicable }} \\
\hline & $\begin{array}{l}\text { Business Development } \\
\text { Manager }\end{array}$ & 99 & 51.83 & & \\
\hline & $\begin{array}{l}\text { Senior Business } \\
\text { Development Manager }\end{array}$ & 48 & 25.13 & & \\
\hline & Area Manager & 12 & 6.28 & & \\
\hline \multirow[t]{3}{*}{ Service Tenure } & 5 to 10 years & 123 & 64.39 & & \\
\hline & 10 to 15 years & 59 & 30.89 & & \\
\hline & Over 15 Years & 09 & 4.71 & & \\
\hline
\end{tabular}


Table 2. Scale items and factor loadings

\begin{tabular}{|c|c|c|}
\hline Constructs - Scale Items & $\begin{array}{c}\text { Outer } \\
\text { loadings }\end{array}$ & VIF \\
\hline \multicolumn{3}{|l|}{ Internal Resource Utilization } \\
\hline Usage of resources available within the organization & 2.27 & 0.66 \\
\hline Optimum resource utilization & 2.37 & 0.71 \\
\hline Use of modern business practices for managing organizational resources & 1.86 & 0.79 \\
\hline $\begin{array}{l}\text { Combination of resources in a manner that extracts value from under- } \\
\text { utilized resources }\end{array}$ & 1.79 & 0.82 \\
\hline Finding new solutions by utilizing resources at hand & 1.73 & 0.82 \\
\hline \multicolumn{3}{|l|}{ External Resource Utilization } \\
\hline $\begin{array}{l}\text { Collaborative arrangements with other businesses for new value } \\
\text { creation }\end{array}$ & 2.32 & 0.84 \\
\hline Promoting the need for development and utilization of new resources & 2.23 & 0.84 \\
\hline Collaboration with educational institutes that focuses on novelty & 2.42 & 0.87 \\
\hline $\begin{array}{l}\text { Collaboration with customers to discover the needs of existing market } \\
\text { segments }\end{array}$ & 2.11 & 0.86 \\
\hline \multicolumn{3}{|l|}{ Value Co-Creation } \\
\hline Involving customers at marketing and branding activities & 1.46 & 0.91 \\
\hline Involving customers at service care & 2.88 & 0.88 \\
\hline Involving customers for new product development & 2.58 & 0.85 \\
\hline Managing customers as partial employee & 2.01 & 0.83 \\
\hline \multicolumn{3}{|l|}{ Incremental Innovation } \\
\hline Regular adaptation of existing services & 2.02 & 0.81 \\
\hline Improved efficiency of providing services & 2.00 & 0.81 \\
\hline Expanding services for existing clients & 2.30 & 0.85 \\
\hline Using improvised ways of providing services & 2.30 & 0.81 \\
\hline Introducing continuous improvements in services for local markets & 3.31 & 0.87 \\
\hline \multicolumn{3}{|l|}{ Radical Innovation } \\
\hline Using advanced technology to produce service & 3.38 & 0.89 \\
\hline Creating totally new services & 3.27 & 0.89 \\
\hline $\begin{array}{l}\text { Changing customers' buying behavior through their usage of new } \\
\text { services }\end{array}$ & 3.85 & 0.90 \\
\hline Using new ways of evaluating quality of services & 3.41 & 0.89 \\
\hline
\end{tabular}




\begin{tabular}{|c|c|c|}
\hline $\begin{array}{l}\text { Prompt addition of new service features in comparison to that of } \\
\text { competitors }\end{array}$ & 2.91 & 0.85 \\
\hline \multicolumn{3}{|l|}{ Tourist Experience } \\
\hline Destination visits feel differently about myself & 2.08 & 0.67 \\
\hline I felt like I was having the ideal experience & 1.86 & 0.64 \\
\hline My actions during this experience were new & 2.96 & 0.78 \\
\hline I truly enjoyed this experience & 3.12 & 0.78 \\
\hline This experience tested my limits & 2.26 & 0.72 \\
\hline The experience was beyond words & 1.76 & 0.71 \\
\hline Co-creative services felt like part of me during the experience & 1.39 & 0.75 \\
\hline I learned new things as a result of this experience & 1.38 & 0.80 \\
\hline I would like to have a similar experience again & 1.18 & 0.73 \\
\hline The experience was emotionally intense & 2.04 & 0.75 \\
\hline After the experience, I felt more positive about myself & 1.56 & 0.66 \\
\hline I still remember the feelings I had during the experience & 1.82 & 0.67 \\
\hline My total attention was on the event & 2.21 & 0.77 \\
\hline $\begin{array}{l}\text { Because of this experience, I have confidence in myself that I didn't } \\
\text { have before }\end{array}$ & 1.63 & 0.75 \\
\hline \multicolumn{3}{|l|}{ Brand Advocacy } \\
\hline I would recommend visiting this destination to others. & 1.20 & 0.88 \\
\hline I love to talk about the good points of this destination to people I know. & 1.20 & 0.80 \\
\hline \multicolumn{3}{|l|}{ Revisit Intentions } \\
\hline How likely is it that you would revisit this destination in the near future? & 1.46 & 0.87 \\
\hline This destination is likely to be my next travelling destination. & 1.46 & 0.91 \\
\hline
\end{tabular}

VIF $=$ Variance Inflation Factor 
Table 3. Reliability and validity

\begin{tabular}{|l|c|c|c|c|}
\hline Constructs & $\begin{array}{c}\text { Cronbach's } \\
\text { Alpha }\end{array}$ & rho_A & $\begin{array}{c}\text { Average } \\
\text { Composite } \\
\text { Reliability }\end{array}$ & $\begin{array}{c}\text { Variance } \\
\text { Extracted } \\
\text { (AVE) }\end{array}$ \\
\hline Internal Resource Orientation & 0.83 & 0.86 & 0.87 & 0.58 \\
\hline External Resource Orientation & 0.88 & 0.89 & 0.92 & 0.73 \\
\hline Incremental Innovation & 0.90 & 0.90 & 0.92 & 0.71 \\
\hline Radical Innovation & 0.93 & 0.93 & 0.95 & 0.78 \\
\hline Value Co-creation & 0.86 & 0.86 & 0.91 & 0.71 \\
\hline Tourist experience & 0.72 & 0.84 & 0.77 & 0.58 \\
\hline Brand Advocacy & 0.72 & 0.73 & 0.88 & 0.78 \\
\hline Revisit Intentions & 0.72 & 0.70 & 0.83 & 0.70 \\
\hline
\end{tabular}

Table 4. Discriminant validity analysis

\begin{tabular}{|l|c|c|c|c|c|c|c|c|}
\hline Constructs & $\mathbf{1}$ & $\mathbf{2}$ & $\mathbf{3}$ & $\mathbf{4}$ & $\mathbf{5}$ & $\mathbf{6}$ & $\mathbf{7}$ & $\mathbf{8}$ \\
\hline 1. Brand Advocacy & $\mathbf{0 . 8 8}$ & & & & & & & \\
\hline 2. Value Co-creation & 0.18 & $\mathbf{0 . 8 4}$ & & & & & & \\
\hline 3. External Resource Orientation & 0.14 & 0.81 & $\mathbf{0 . 8 5}$ & & & & & \\
\hline 4. Incremental Innovation & 0.18 & 0.78 & 0.76 & $\mathbf{0 . 8 4}$ & & & & \\
\hline 5. Internal Resource Orientation & 0.09 & 0.58 & 0.70 & 0.57 & $\mathbf{0 . 7 6}$ & & & \\
\hline 6. Radical Innovation & 0.09 & 0.74 & 0.72 & 0.81 & 0.62 & $\mathbf{0 . 8 8}$ & & \\
\hline 7. Revisit Intentions & 0.15 & 0.16 & 0.17 & 0.14 & 0.42 & 0.10 & $\mathbf{0 . 8 4}$ & \\
\hline 8. Tourist experience & 0.53 & 0.06 & 0.05 & 0.04 & 0.32 & 0.07 & 0.13 & $\mathbf{0 . 7 6}$ \\
\hline
\end{tabular}

Note: Figures in bold on the diagonal are the square roots of the average variance extracted (AVE) 
Table 5. Hypothesis results

\begin{tabular}{|c|c|c|c|c|c|c|}
\hline & $\begin{array}{c}\text { Original } \\
\text { Sample } \\
\text { (O) }\end{array}$ & $\begin{array}{c}\text { Sample } \\
\text { Mean } \\
\text { (M) }\end{array}$ & $\begin{array}{l}\text { Standard } \\
\text { Deviation } \\
\text { (STDEV) }\end{array}$ & $\begin{array}{c}T \\
\text { Statistics }\end{array}$ & $\begin{array}{c}P \\
\text { Value }\end{array}$ & Result \\
\hline H1a: Internal Resource Orientation $\rightarrow$ Incremental Innovation & 0.06 & 0.05 & 0.10 & 0.64 & 0.53 & Not supported \\
\hline H1b: Internal Resource Orientation $\rightarrow$ Radical Innovation & 0.19 & 0.17 & 0.11 & 1.79 & 0.07 & Not supported \\
\hline H2a: External Resource Orientation $\rightarrow$ Incremental Innovation & 0.34 & 0.33 & 0.11 & 3.46 & 0.003 & Supported \\
\hline H2b: External Resource Orientation $\rightarrow$ Radical Innovation & 0.21 & 0.20 & 0.09 & 2.32 & 0.02 & Supported \\
\hline H3a: Internal Resource Orientation $\rightarrow$ Value Co-creation & 0.58 & 0.58 & 0.05 & 10.93 & 0.001 & Supported \\
\hline H3b: External Resource Orientation $\rightarrow$ Value Co-creation & 0.81 & 0.81 & 0.03 & 3.58 & 0.001 & Supported \\
\hline H4a: Value Co-creation $\rightarrow$ Incremental Innovation & 0.47 & 0.49 & 0.11 & 4.46 & 0.001 & Supported \\
\hline H4b: Value Co-creation $\rightarrow$ Radical Innovation & 0.46 & 0.48 & 0.11 & 4.37 & 0.001 & Supported \\
\hline H7a: Incremental Innovation $\rightarrow$ Tourist experience & 0.28 & 0.29 & 0.14 & 2.01 & 0.05 & Supported \\
\hline H7b: Radical Innovation $\rightarrow$ Tourist experience & 0.30 & 0.31 & 0.13 & 2.39 & 0.02 & Supported \\
\hline H8a: Tourist experience $\rightarrow$ Brand Advocacy & 0.53 & 0.54 & 0.07 & 7.86 & 0.001 & Supported \\
\hline H8b: Tourist experience $\rightarrow$ Revisit Intentions & 0.48 & 0.12 & 0.13 & 1.06 & 0.001 & Supported \\
\hline
\end{tabular}


Table 6. Mediation analysis

\begin{tabular}{|l|c|c|c|c|c|c|}
\hline & \multicolumn{2}{|c|}{ Value Accounted For (VAF) } & & & \\
\hline Path & $\begin{array}{c}\text { Original } \\
\text { Sample } \\
\mathbf{( O )}\end{array}$ & $\begin{array}{c}\text { Sample } \\
\text { Mean } \\
\mathbf{( M )}\end{array}$ & $\begin{array}{c}\text { Standard } \\
\text { Deviation } \\
\text { (STDEV) }\end{array}$ & $\begin{array}{c}\text { T } \\
\text { Statistics }\end{array}$ & $\begin{array}{c}\text { P } \\
\text { Value }\end{array}$ & Result \\
\hline $\begin{array}{l}\text { H5a: Internal Resource Orientation } \rightarrow \text { Value } \\
\text { Co-creation } \rightarrow \text { Incremental Innovation }\end{array}$ & 0.54 & 0.54 & 0.07 & 7.77 & 0.001 & Full Mediation \\
\hline $\begin{array}{l}\text { H5b: Internal Resource Orientation } \rightarrow \text { Value } \\
\text { Co-creation } \rightarrow \text { Radical Innovation }\end{array}$ & 0.48 & 0.48 & 0.07 & 6.51 & 0.001 & Full Mediation \\
\hline $\begin{array}{l}\text { H6a: External Resource Orientation } \rightarrow \text { Value } \\
\text { Co-creation } \rightarrow \text { Radical Innovation }\end{array}$ & 0.01 & 0.02 & 0.05 & 0.09 & 0.93 & No Mediation \\
\hline $\begin{array}{l}\text { H6b: External Resource Orientation } \rightarrow \text { Value } \\
\text { Co-creation } \rightarrow \text { Incremental Innovation }\end{array}$ & 0.01 & 0.02 & 0.06 & 0.09 & 0.93 & No Mediation \\
\hline
\end{tabular}

